\title{
KERAJINAN WAYANG GOLEK SEBAGAI PRODUK UNGGULAN DAERAH UNTUK PEMBERDAYAAN EKONOMI DESA TEGALWARU
}

\author{
M.I. Qeis ${ }^{1}$, Agung Zainal Muttakin Raden ${ }^{* 2}$, Santi Sidhartani ${ }^{3}$, Dendi Pratama ${ }^{4}$ \\ ${ }_{1,2,3,4}$ Program Studi Desain Komunikasi Visual, Fakultas Bahasa dan Seni \\ Universitas Indraprasta PGRI; J1. Nangka No 58.C Jagakarsa Jakarta, 021-781878 \\ e-mail: agung.zainalmr@unindra.ac.id
}

\begin{abstract}
Tegalwaru Village has tried to develop by making itself a tourism village for Micro, Small, and Medium Enterprises (MSMEs) since 2018. However, the MSMEs have difficulty establishing their identity in the business world due to the lack of regional specialty products. Therefore, there is a need to innovate the regional specialty products as one of the efforts to improve the village's economy by considering the potential and uniqueness of the resources available in Tegalwaru Village. As part of the community service program, research on specialty products in this area uses qualitative methods through observation and in-depth interviews. The result shows that one of the potential MSMEs of Tegalwaru Village that can be developed as a regional specialty product is Wayang Golek craft. The implication of this study is to offer perspective on deciding regional specialty product and increasing local MSME production by innovating to strengthen the position of local MSMEs in market competition.
\end{abstract}

Keywords-MSME, Wayang Golek, Tegalwaru Village, Regional Specialty Product, Village Empowerment

\begin{abstract}
Abstrak
Desa Tegalwaru telah mencoba berkembang dengan menjadikan diri sebagai kampung wisata Usaha Mikro, Kecil, dan Menengah (UMKM) semenjak tahun 2018. Namun, UMKM Desa Tegalwaru memiliki kesulitan menetapkan identitas dirinya dalam dunia bisnis karena kurangnya produk yang memiliki keunikan dan unggul dalam persaingan pasar. Oleh karena itu, dibutuhkan suatu inovasi produk unggulan daerah yang dapat meningkatan ekonomi masyarakat melalui pengembangan iptek dengan memperhatikan potensi dan keunikan yang dimiliki oleh sumber daya di Desa Tegalwaru. Sebagai bagian dari program pengabdian masyarakat, riset mengenai produk unggulan daerah ini menggunakan metode kualitatif dalam bentuk studi kelayakan lapangan melalui observasi dan wawancara mendalam. Hasil dari studi ini menemukan bahwa salah satu potensi UMKM Desa Tegalwaru yang dapat dijadikan produk unggulan daerah adalah kerajinan Wayang Golek. Implikasi dari riset ini adalah penawaran perspektif dalam penentuan produk unggulan daerah dan solusi peningkatan kemampuan UMKM melalui inovasi ragam produk untuk mengukuhkan posisi UMKM dalam persaingan pasar.
\end{abstract}

Kata kunci-UMKM, Wayang Golek, Desa Tegalwaru, Produk Unggulan Daerah, Pemberdayaan Desa

\section{PENDAHULUAN}

$\mathbf{I}_{\mathrm{n}}^{\mathrm{n}}$ ndonesia merupakan salah satu negara dengan jumlah penduduk terbesar di dunia. Hal ini memberikan dampak pada proses pemerataan pertumbuhan ekonomi masyarakat. Jumlah penduduk yang besar dapat menjadi peluang dalam hal ketersediaan sumber daya manusia, namun juga dapat menjadi permasalahan apabila tidak ada pengelolaan sumber daya manusia yang tepat. Berbagai persoalan sosial seperti masalah penggangguran banyak bermunculan dan mengganggu pertumbuhan perekonomian masyarakat. Untuk mengatasi hal tersebut, pemerintah Indonesia saat ini mulai membangun sistem ekonomi yang didasarkan pada pengembangan IPTEK dan inovasi. Salah satu penerapannya adalah dengan mengembangkan Produk Unggulan Daerah yang memiliki 
potensi bisnis melalui pemberdayaan masyarakat. Seperti dilansir oleh Koran Sindo (2019), pemerintah akan mendorong universitas untuk mengembangkan produk unggulan daerah berbasis teaching industry berdasarkan sumber daya alam yang tersedia di daerah setempat. [1]

Sebagai bagian dari program pengabdian masyarakat, pengembangan Produk Unggulan Daerah harus mampu dilakukan oleh universitas sebagai salah satu upaya peningkatan ekonomi masyarakat yang dilakukan dengan mengembangkan IPTEK dan melakukan inovasi. Target utama dari pengembangan Produk Unggulan Daerah ini adalah Usaha Mikro, Kecil, dan Menengah (UMKM). Undang-undang no.20 tahun 2018 tentang Usaha Mikro, Kecil, dan Menengah menyebutkan bahwa: (1). Usaha Mikro adalah usaha produktif milik perorangan dengan kekayaan bersih paling banyak 50 Juta dan penjualan tahunan paling banyak 300 juta; (2). Usaha Kecil adalah usaha ekonomi produktif yang berdiri sendiri dengan kekayaan bersih antara 50 juta sampai 500 juta dan penjualan tahunan antara 300 juta sampai 2,5 milyar; (3). Usaha Menengah adalah usaha ekonomi produktif yang berdiri sendiri dengan kekayaan bersih antara 500 juta sampai 10 milyar dan penghasilan tahunan antara 2,5 milyar sampai 50 milyar.

Pengabdian masyarakat berupa pengembangan produk unggulan daerah berbasis pemberdayaan UMKM ini juga memiliki visi yang sejalan dengan apa yang dikatakan oleh Arif Budimanta selaku wakil ketua Komite Ekonomi dan Industri Nasional. Seperti dilansir oleh CNN (2019), Budimanta mengatakan bahwa pemberdayaan UMKM dapat mempersempit ketimpangan sosial dan ekonomi di Indonesia.[2] Dikarenakan target dari pengembangan Produk Unggulan Daerah adalah UMKM yang dikelola oleh masyarakat setempat sehingga dapat memberdayakan potensi ekonomi kreatif pada masyarakat, potensi ekonomi masyarakat setempat dan kemampuan UMKM harus diriset secara mendalam untuk mengetahui jenis produk yang tepat untuk dikembangkan sebagai Produk Unggulan Daerah.

Salah satu desa yang yang menjadi sasaran pengembangan Produk Unggulan Daerah adalah Desa Tegalwaru yang terletak di kecamatan Ciampea, Bogor. Desa Tegalwaru. Dalam artikel yang ditulis oleh GoUKM.id (2016), Desa Tegalwaru pada awalnya adalah salah satu desa tertinggal dengan tingginya masyarakat yang putus sekolah dan kesulitan mendapatkan pekerjaan.[3] Namun, sejak tahun 2018, Bupati Bogor menetapkan Desa Tegalwaru sebagai kampung wisata UMKM. Berdasarkan wawancara terhadap Ibu Rara sebagai perwakilan dari yayasan KUNTUM yang mengelola kampung wisata bisnis Tegalwaru, saat ini sudah terdapat peningkatan ekonomi masyarakat yang signifikan di Desa Tegalwaru semenjak penetapannya sebagai kampung wisata bisnis UMKM.

Namun, UMKM Desa Tegalwaru memiliki kesulitan dalam bersaing di dunia bisnis untuk terus mengembangkan pemberdayaan masyarakat desa. Hal ini sesuai dengan argumen Wong dan Merrilees (2005:155) bahwa UMKM memiliki kesulitan menetapkan identitas diri nya di persaingan dunia bisnis karena adanya keterbatasan kemampuan.[4] Perkembangan di bidang teknologi informasi adalah salah satu faktor yang mempengaruhi peningkatan persaingan bisnis pada pasar regional maupun global. Dengan adanya faktor perkembangan teknologi informasi, produsen diharapkan mampu menawarkan dan menghasilkan produk yang memiliki keunikan tinggi dan inovatif pada pasarnya. Oleh karena itu, dengan peluang yang dimiliki Indonesia sebagai negara yang kaya tradisi dan budaya, maka sangat terbuka alternatif dalam pengembangan produk daerah berbasis kekayaan budaya yang dapat diangkat menjadi Produk Unggulan Daerah. Pengembangan produk berbasis kekayaan budaya inilah yang perlu untuk dikembangkan oleh banyaknya UMKM yang berada di Desa Tegalwaru agar desa tersebut dapat terus menyandang predikatnya sebagai kampung wisata bisnis UMKM.

\section{METODE}

Riset dalam pelaksanaan program pengabdian masyarakat ini dilakukan di Desa Tegalwaru yang memiliki identitas sebagai kampung wisata bisnis UMKM untuk menemukan potensi yang sesuai berdasarkan sumber daya yang dimiliki oleh Desa Tegalwaru untuk digarap menjadi salah satu Produk Unggulan Daerah. Metode yang digunakan adalah metode kualitatif dalam bentuk studi kelayakan lapangan melalui observasi dan wawancara mendalam. Dalam riset terkait pengembangan Produk Unggulan Daerah, fokusan pendekatan yang digunakan sesuai dengan apa 
yang dikemukakan oleh Gundala dan Khawaja (2014) yang meliputi empat fokusan, yaitu: (1) Pengumpulan informasi; (2) Identifikasi sasaran; (3) Inovasi, dan; (4) Pemasaran interaktif.

Keempat fokusan yang dikemukakan di atas dilakukan secara bertahap dalam riset terkait pengembangan Produk Unggulan Daerah di Desa Tegalwaru. Tahapan awal berupa pengumpulan data dilakukan melalui observasi dan wawancara mendalam untuk memetakan potensi dan hambatan dalam proses pemberdayaan UMKM Desa Tegalwaru. Tahapan kedua yaitu identifikasi sasaran dilakukan untuk melihat potensi kontribusi masyarakat terhadap aspek ekonomi produk sebagai turis atau wisatawan agar didapatkan spesifikasi potensi produk yang cocok untuk dikembangkan dalam usaha pemberdayaan UMKM. Tahapan ketiga dilakukan dengan menentukan konsep desain secara kualitatif berdasarkan data-data yang telah didapat dari tahapan sebelumnya. Tahapan terakhir dilakukan dengan menggunakan sosial media dan jaringan internet dalam rangka melakukan diseminasi dan pembuatan katalog produk agar dapat diakses oleh pasaran yang lebih luas. Sebagai bagian dari riset program pengabdian masyarakat, tahapan yang akan difokuskan dalam artikel ini adalah tahapan satu sampai tahapan tiga sebagai upaya menemukan potensi dan konsep inovasi berupa desain Produk Unggulan Daerah di Desa Tegalwaru.

Dalam pelaksanaan program pengabdian masyarakat terkait pemberdayaan UMKM, perlu dipahami terlebih dahulu karakteristik dari UMKM. Hafni dan Rozali mengemukakan bahwa terdapat empat karakteristik umum yang dimiliki oleh UMKM yaitu: (1) Tidak adanya pembagian bidang administrasi dan operasi; (2) Rendahnya akses terhadap lembaga kredit formal; (3) Sebagian besar belum memiliki status badan hukum, dan; (4) Golongan industrinya sebagian besar meliputi industri makanan, minuman, kayu, tekstil, dan perabotan rumah tangga [5]. Dari karakteristik di atas, dapat dilihat bahwa UMKM yang ada secara umum masih belum memasukkan unsur ragam budaya ke dalam produk-produknya. Oleh karena itu, dalam riset penentuan Produk Unggulan Daerah dari kampung wisata bisnis UMKM Desa Tegalwaru ini, perlu ditemukan UMKM yang unik dengan basis keragaman budaya Indonesia agar dapat memperluas persaingan UMKM Desa Tegalwaru sebagai bagian dari pemberdayaan ekonomi masyarakat.

\section{HASIL DAN PEMBAHASAN}

Desa Tegalwaru merupakan sebuah kampung wisata bisnis UMKM yang mengangkat beragam produk industri dan tersebar di masyarakatnya dalam bentuk usaha-usaha mikro dan usaha kecil. Tahapan pertama yang dilakukan dalam riset ini adalah pengumpulan informasi melalui observasi dan wawancara. Terdapat 18 UMKM dalam Desa Tegalwaru yang mencakup berbagai golongan industri seperti UMKM tas, herbal, kerupuk, sandal, risol, budidaya ikan, dan ketupat. Namun, sebagian besar dari UMKM di Desa Tegalwaru masih terfokus pada golongan industri yang menjadi karakteristik UMKM pada umumnya seperti dikemukakan sebelumnya oleh Hafni dan Rozali. Selama dilakukan observasi ke Desa Tegalwaru, terdapat dua UMKM yang memiliki potensi untuk dikembangkan menjadi Produk Unggulan Daerah karena adanya nilai kekayaan budaya Indonesia yang terwujud di alam produknya yaitu UMKM Wayang Golek dan UMKM Gendang. Setelah dilakukan observasi secara seksama terhadap sumber daya alam dan sumber daya manusia serta wawancara mendalam terhadap pihak pengelola kampung wisata dan wawancara terhadap pengrajin, program pengabdian masyarakat ini pun memilih UMKM Wayang Golek sebagai UMKM yang akan diberdayakan dan dikembangkan sebagai Produk Unggulan Daerah dari Desa Tegalwaru.

Saat ini UMKM Wayang Golek yang ada di Desa Tegalwaru ini terus mengalami perkembangan. Berdasarkan wawancara terhadap Risnajaya sebagai pendiri usaha kerajinan Wayang Golek di Desa Tegalwaru, diketahui bahwa usaha ini telah mulai ditekuni sejak tahun 1984. Saat ini produk yang dihasilkan pada UMKM Wayang Golek ini berupa boneka wayang yang dapat dimainkan seperti yang digunakan oleh dalang Wayang Golek. Dari aspek kualitas produksi, produk yang dihasilkan memiliki kualitas yang baik dan telah dipasarkan hingga ke luar negeri. Produksi Wayang Golek yang dihasilkan mencapai lebih dari 100 karakter tokoh wayang. Hal ini menjadi kekuatan produk dari segi pilihan karater tokoh. Tokoh-tokoh yang dibuat pun sama dengan tokoh yang ada pada cerita pewayangan. Hal ini sesuai dengan upaya untuk 
mempertahankan nilai tradisi dan budaya yang dimiliki oleh Wayang Golek sebagai produk budaya.

Tahapan kedua adalah tahapan identifikasi sasaran. Berdasarkan wawancara terhadap Ibu Rara, banyak sekali pengunjung kampung wisata bisnis UMKM Desa Tegalwaru yang menginginkan banyaknya ketersediaan produk Wayang Golek yang dapat dibeli sebagai souvenir khas Desa Tegalwaru. Oleh karena itu, dari segi identifikasi sasaran, UMKM Wayang Golek memiliki potensi produk yang cocok untuk dikembangkan sebagai Produk Unggulan Daerah. Selain itu, hasil wawancara terhadap Risnajaya juga menjadi dasar dari pemilihan UMKM Wayang Golek yang mencakup tiga aspek utama, yaitu sumber daya alam, sumber daya manusia, dan keunikan produk yang akan diangkat.

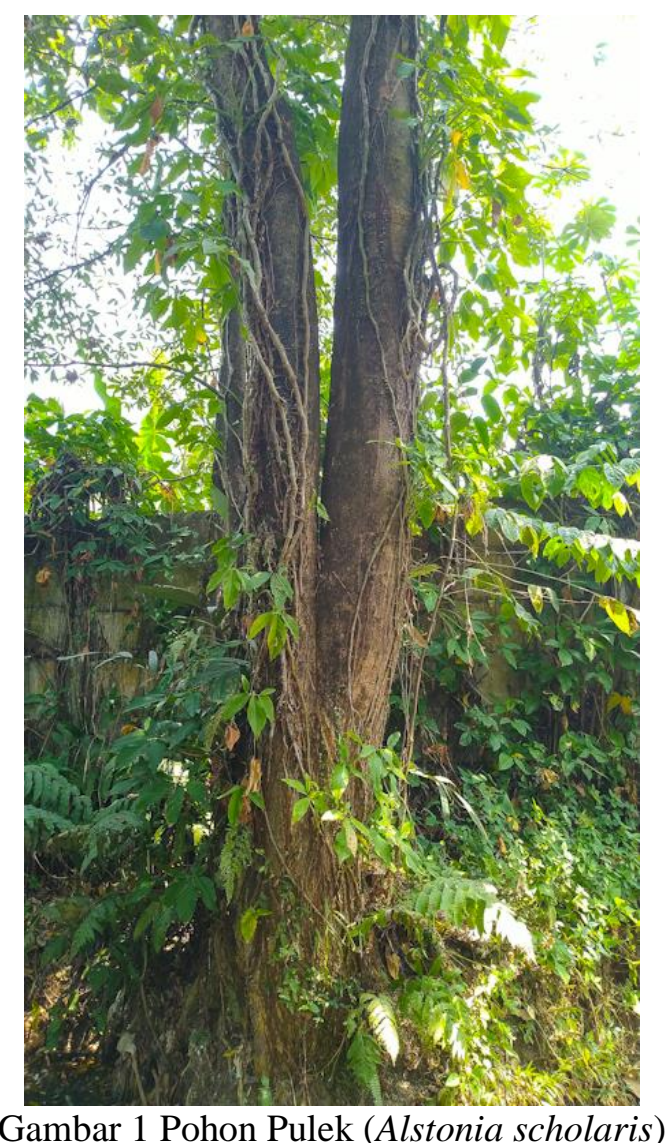

Aspek pertama yang menjadi dasar pemilihan UMKM Wayang Golek adalah aspek sumber daya alam. Rukiah mendeskripsikan wayang golek sebagai boneka tiga dimensi yang dibuat dari kayu dan pada bagian bawah dan kaki nya dibalut dengan pakaian [6]. Oleh karena itu, kayu sebagai bahan dasar pembuatan wayang golek harus dapat dipastikan ketersediaannya. Berdasarkan wawancara terhadap Risnajaya, kayu yang dipakai dalam pembuatan wayang golek pada UMKM Wayang Golek di Desa Tegalwaru adalah kayu pulek. Gambar 1 memperlihatkan pohon pulek yang dikenal juga dengan nama pohon pulai dengan nama latin Alstonia scholaris. Pohon ini dapat dengan mudah ditemukan tumbuh di daerah Desa Tegalwaru, terutama di jalan Pulekan tempat UMKM Wayang Golek berada. Oleh karena itu, dari aspek sumber daya alam, UMKM Wayang Golek tepat untuk dikembangkan menjadi Produk Unggulan Daerah.

Selain itu, walaupun menggunakan kayu dari pohon yang tumbuh di sekitar Desa Tegalwaru, keberlanjutan industri wayang golek ini juga tidak merugikan lingkungan hidup. UU no.20 tahun 2008 tentang Usaha Mikro, Kecil, dan Menengah secara spesifik mengatur dalam Bab 2 pasal 2 bahwa UMKM harus berasaskan berwawasan lingkungan dengan tetap memperhatikan dan mengutamakan perlindungan dan pemeliharaan lingkungan hidup. Oleh karena itu, dalam mengusung UMKM Wayang Golek sebagai Produk Unggulan Daerah, keberlangsungan lingkungan hidup menjadi penting untuk dipertimbangkan dalam aspek sumber daya alam. 
Berdasarkan wawancara terhadap Risnajaya, satu batang yang didapat dari pohon pulek dapat dipakai untuk membuat 100 wayang golek berukuran besar. Setiap Risnajaya hendak menebang pohon Pulek, Risnajaya terlebih dahulu melakukan pembibitan secara vegetatif dengan setek ranting untuk menanam anakan-anakan pohon agar tetap menjaga keberlangsungan sumber daya alam nya. Anakan pohon pulek seperti terlihat pada gambar 2 akan tumbuh menjadi pohon dewasa dalam jangka waktu sekitar 5-10 tahun.

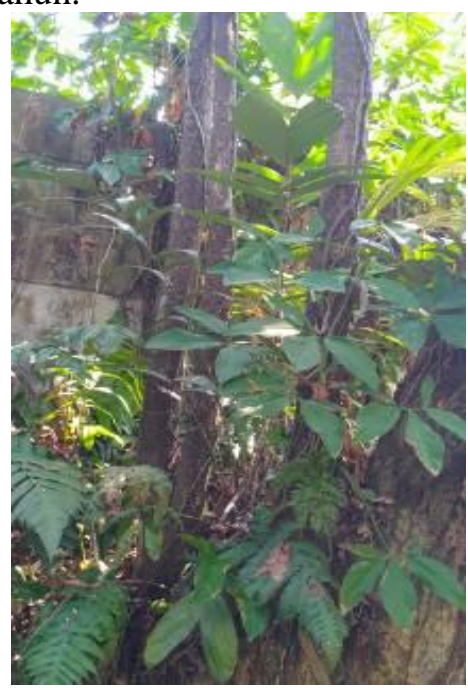

Gambar 2 Anakan Pohon Pulek hasil stek ranting usia 1 tahun yang ditanam di belakang pohon induk

Aspek kedua yang menjadi dasar pemilihan UMKM Wayang Golek adalah aspek sumber daya manusia. Sebagai pengrajin, Risnajaya memiliki teknik khas yang menjadikan wayang golek buatan nya berbeda dengan wayang golek pada umumnya. Teknik pembuatan ini dapat dilihat salah satunya dari teknik pewarnaan yang dilakukan. Gambar 3 memperlihatkan perbedaan warna dan detail ukiran dari wayang golek yang dibuat di UMKM Wayang Golek Desa Tegalwaru dengan wayang golek yang banyak ditemukan di pasaran, terutama di toko-toko dalam jaringan.

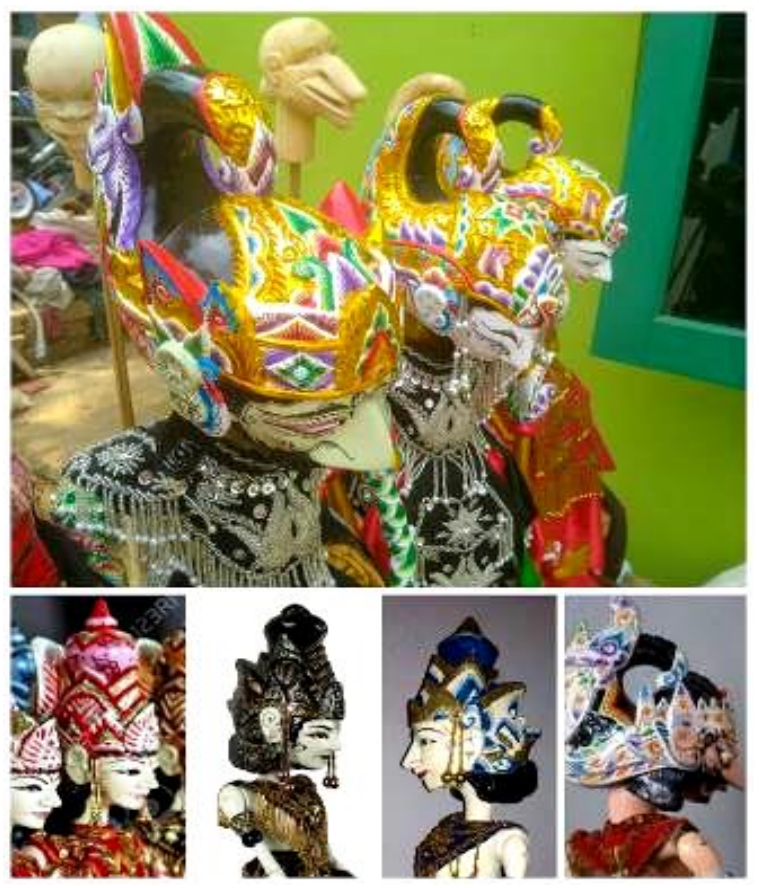

Gambar 3 Perbandingan wayang golek dari Tegalwaru (atas) dengan wayang golek yang umum dijual (bawah) 
Wayang golek yang umum dijual yang terlihat pada gambar 3 diambil dari foto produk yang dijual pada toko-toko dalam jaringan baik itu berskala nasional seperti Tokopedia dan OLX, ataupun yang berskala internasional seperti eBay. Dalam toko berskala nasional, kisaran harga wayang golek besar adalah antara 500 ribu hingga 1 juta Rupiah. Sementara kisaran harga jual wayang golek besar di toko berskala internasional ada di sekitaran 60 Dollar Amerika. Dapat dilihat dari teknik pewarnaan saja, pengrajin di UMKM Wayang Golek Desa Tegalwaru memiliki keunikan dalam hal pewarnaan yang lebih menyala dan terang serta menarik perhatian. Pemadanan unsur emas dengan warna terang dalam teknik pewarnaan ini menjadikan wayang golek hasil kerajinan tersebut lebih menarik dan cocok untuk dipertimbangkan menjadi salah satu Produk Unggulan Daerah Desa Tegalwaru yang bernilai tinggi.

Aspek ketiga yang menjadikan dasar pemilihan UMKM Wayang Golek adalah keunikan produk yang akan diangkat. Dari 18 UMKM yang terdapat di Desa Tegalwaru, sebagian besar bergerak di golongan industri makanan dan barang pakai seperti UMKM kerupuk, risol, brownies, ketupat, herbal, tas, dan pakaian kulit. Sementara itu, berdasarkan tahapan ketiga yang dikemukakan oleh Gundala dan Khawaja sebagai fokusan tahapan yaitu inovasi, dibutuhkan suatu produk yang dapat menjadi tawaran inovasi baru dalam persaingan pasar. Oleh karena itu, pemilihan UMKM Wayang Golek didasari atas kemudahan dalam inovasi yang dapat dilakukan untuk menciptakan produk kerajinan baru yang dapat bersaing di pasaran.

Meskipun telah disebutkan bahwa UMKM Wayang Golek yang ada di Desa Tegalwaru ini terus mengalami perkembangan, namun masih ada beberapa kendala yang dihadapi oleh pengrajin seperti terbatasnya pemasaran dan modal untuk mengembangkan usahanya. Hal ini sesuai dengan apa yang dikemukakan Murdani, Widayani, dan Hadromi mengenai permasalahan yang harus diupayakan solusinya bagi UMKM yang meliputi lima dimensi pendekatan, yaitu: (1) Bantuan modal; (2) Bantuan pengembangan prasarana; (3) Pengembangan kelembagaan lokal; (4) Penguatan pembangunan kemitraan usaha, dan; (5) Fasilitas pendampingan [7]. Selama ini permodalan menjadi kendala yang cukup besar dari pengembangan usaha ini. Karena adanya keterbatasan modal, maka wayang golek hanya bisa diproduksi berdasarkan dana yang diterima dari pemesanan yang ada. Permasalahan lainnya adalah belum adanya ciri khas visual sebagai identitas unik yang membedakan hasil kerajinan wayang golek desa Tegalwaru dengan kerajinan wayang golek umumnya di pasaran. Berdasarkan wawancara dengan Risnajaya, fokusan utama UMKM kerajinan wayang golek adalah memenuhi pemesanan yang ada sehingga belum ada pengembangan terutama dalam bidang pengetahuan dan kesadaran terhadap produk sebagai sesuatu yang unik.

Untuk mengatasi permasalahan tersebut, program pengabdian masyarakat dalam pengembangan Produk Unggulan Daerah ini mencoba menawarkan solusi terutama dalam dimensi bantuan modal berupa alat-alat produksi untuk meningkatkan produktivitas kerja. Pada dimensi bantuan modal, beberapa alat produksi yang kami sediakan didasari atas wawancara mendalam dan observasi proses produksi kerajinan wayang golek. Alat-alat yang disediakan untuk membantu produksi ini dapat dilihat pada gambar 4 dan 5 yang di antaranya mencakup mesin jahit, gergaji mesin, dan airbrush untuk memudahkan proses pewarnaan.

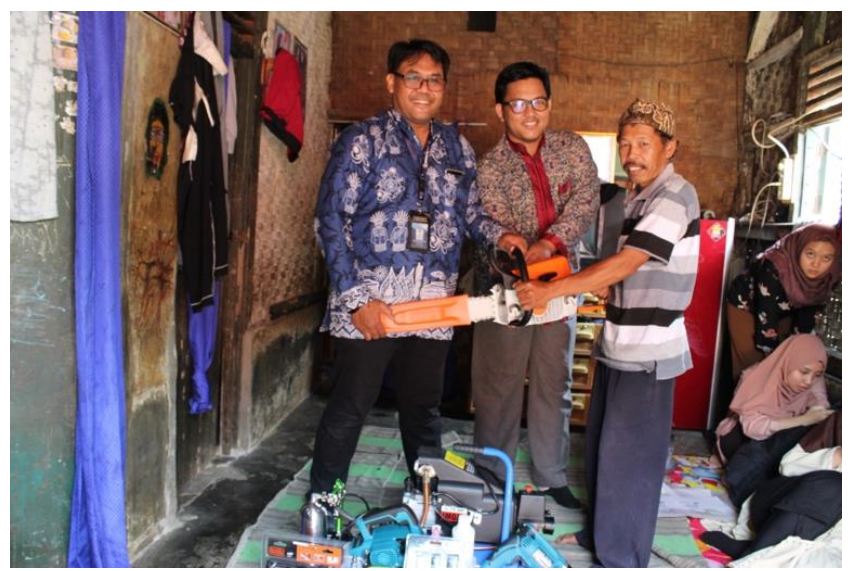

Gambar 4 Bantuan modal berupa alat-alat produksi 


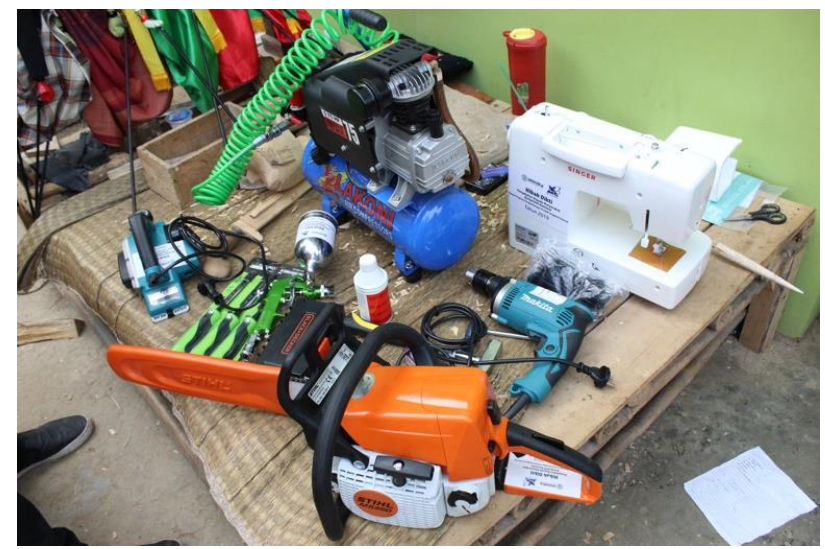

Gambar 5 Bantuan modal berupa alat-alat produksi

Pemberian modal dalam bentuk alat-alat produksi dan bukan dalam bentuk dana cair dilakukan berdasarkan riset mengenai permasalahan utama yang banyak dihadapi oleh UMKM di Indonesia. Tambunan menyebutkan bahwa dalam data riset tahun 2015, permasalahan utama yang dihadapi oleh UMKM di Indonesia adalah kesulitan modal usaha dalam bentuk penyediaan alat produksi.[8] Oleh karena itu, penyediaan alat produksi menjadi penting dalam dimensi bantuan modal untuk meningkatkan daya saing dan kinerja UMKM. Hal ini dilakukan untuk menjawab permasalahan yang muncul pada tahapan identifikasi pasar yaitu kurangnya produk yang dicari oleh pasar dan konsumen diakibatkan kekurangan modal dalam proses produksi.

Selain dimensi bantuan modal, bantuan pelatihan dan pengembangan inovasi ragam produk yang dapat bersaing di pasaran juga dilakukan sebagai bagian dari dimensi fasilitas pendampingan. Rohayati dan Wulandari berargumen bahwa salah satu dimensi bantuan pelatihan yang paling dibutuhkan dalam pengembangan UMKM adalah pelatihan dalam pengembangan produk.[9] Selama ini UMKM Wayang Golek Desa Tegalwaru hanya membuat wayang golek berukuran besar untuk digunakan sebagai kebutuhan perdalangan. Hal ini disebabkan UMKM Wayang Golek Desa Tegalwaru masih bergantung kepada pertimbangan laba/rugi dalam perhitungan nilai ekonomi, sehingga hanya memproduksi permintaan yang datang langsung dan tidak dapat mengerjakan produksi-produksi sampingan yang dapat dijual secara bebas.

Pengerjaan berdasarkan permintaan ini kemudian menjadi masalah baru karena tidak adanya inovasi yang dilakukan untuk menjawab permintaan pasar akan benda kerajinan yang dapat diakses mudah tanpa perlu menaruh permintaan awal. Berdasarkan riset yang dilakukan oleh Ionita, hal ini disebabkan karena banyak UMKM yang hanya mementingkan visi kepuasan pribadi dibandingkan visi pendirian bisnis sehingga mereka tidak memikirkan sisi profit jangka panjang.[10] Oleh karena itu, perlu untuk dipikirkan strategi pengembangan produk yang dapat mendatangkan profit namun tetap sesuai dengan visi pribadi pemilik UMKM dan tidak kehilangan nilai tradisi dan budaya yang ingin dikedepankan. Salah satu inovasi yang ditawarkan adalah pembuatan produk kerajinan kepala wayang golek sebagai hiasan magnet seperti yang terlihat pada gambar 6.

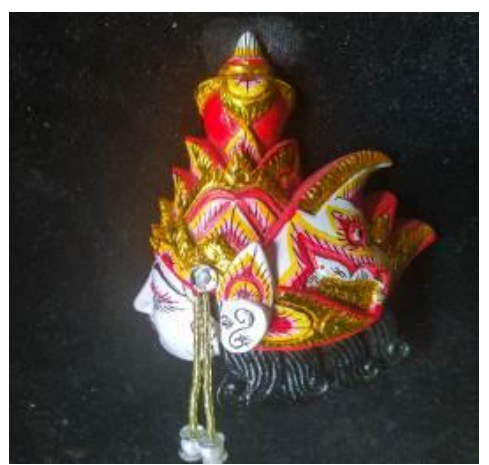

Gambar 6 Produk hiasan magnet kepala tokoh wayang golek 
Secara ukuran, produk kerajinan kepala wayang golek sebagai hiasan magnet ini memiliki dimensi yang relatif kecil yaitu sekitar $7 \times 5 \mathrm{~cm}$ dengan ketebalan sekitar $2-3 \mathrm{~cm}$ sehingga tidak memerlukan bahan yang banyak dalam pembuatannya. Selain itu, produk ini akan dapat menarik banyak pasar konsumen yang lebih spontan dan massal untuk mengenal keunikan wayang golek dari UMKM Wayang Golek Desa Tegalwaru dan menambah potensi untuk pengembangan skala baik modal maupun sumber daya manusia dari UMKM tersebut. Pengembangan produk ini pun tidak mengurangi nilai budaya yang terdapat pada wayang golek karena produk hiasan magnet ini dapat dibuat sebagai salah satu media pengenalan tokoh-tokoh wayang kepada masyarakat umum melalui media populer. Sebagai cinderamata, hiasan magnet ini pun dapat diperjual belikan secara massal untuk menambah modal bagi produksi-produksi selanjutnya sehingga visi bisnis untuk mendatangkan profit pun bisa dipenuhi.

\section{KESIMPULAN}

Kegiatan ini berencana untuk menetapkan potensi yang dimiliki oleh Desa Tegalwaru untuk kemudian dikembangkan menjadi suatu Produk Unggulan Daerah yang bersaing. Pengembangan Produk Unggulan Daerah memerlukan riset yang mendalam untuk menemukan potensi yang dimiliki oleh suatu daerah. Walaupun kegiatan ini dilakukan di Desa Tegalwaru yang menjadi rumah bagi 18 UMKM, namun pada kenyataan nya tidak semua UMKM dapat diolah secara inovatif untuk dijadikan suatu Produk Unggulan Daerah. Terutama ketika pengembangan ini bertujuan untuk tidak hanya memajukan ekonomi rakyat, tetapi juga untuk mengukuhkan Indonesia sebagai salah satu negara yang disegani di dunia internasional. Dengan mempertimbangkan kekayaan budaya yang dimiliki sebagai nilai penting yang menjadikan Indonesia berbeda dari negara-negara lain nya di dunia, maka pengembangan Produk Unggulan Daerah pun perlu memasukkan nilai-nilai budaya ke dalam produk yang ditawarkan sebagai identitas pembeda yang unik yang diharapkan dapat menjadi kekuatan untuk bertahan di pasar dalam era revolusi industri 4.0 ini.

UMKM Wayang Golek dipilih karena berbagai potensi yang dimiliki nya untuk menjadi Produk Unggulan Daerah dari Desa Tegalwaru. Potensi itu dapat dilihat dari tiga aspek yaitu sumber daya alam dalam bentuk ketersediaan bahan mentah yang berkesinambungan, sumber daya manusia dalam bentuk teknik kerajinan yang khas dan unik, serta keunikan produk yang berbeda jika dibandingkan dengan UMKM yang berkembang di sekitarnya. Namun, saat ini UMKM Wayang Golek terhambat oleh beberapa faktor terutama pada faktor modal produksi dan inovasi di mana kerajinan wayang golek yang dihasilkan belum mampu untuk dapat menjawab permintaan pasar. Solusi untuk memecahkan masalah ini sangat penting dilakukan karena keistimewaan produk yang ditawarkan UMKM Wayang Golek Desa Tegalwaru dapat menjadi pembeda yang mengarahkan pasar untuk membeli produk yang dihasilkan.

Kerajinan wayang golek yang dihasilkan memiliki kualitas yang baik, namun ukuran produk wayang yang terbatas pada ukuran besar untuk keperluan pedalangan perlu dikembangkan dalam bentuk inovasi-inovasi yang tepat guna agar Produk Unggulan Daerah yang dihasilkan dapat menjadi daya tarik khas Bogor sehingga perlu inovasi terutama pada segi kesesuain ukuran dan variasi produknya. Diharapkan dengan adanya peningkatan dalam proses produksi dan penguatan inovasi produk kerajinan, UMKM Wayang Golek Desa Tegalwaru dapat membantu pemberdayaan dan pengembangan ekonomi masyarakat sehingga berdampak pada peningkatan pengetahuan dan kemampuan bersaing dari para pengrajin sebagai SDM yang berperan serta, baik dalam peningkatan ekonomi bangsa maupun dalam menjaga khasanah budaya asli nusantara.

\section{SARAN}

Bagi pengrajin wayang golek diharapkan mampu berinovasi sesuai dengan trend saat ini. Transformasi tradisi diperlukan untuk mempertahankan tradisi di era digital saat ini. Konsistensi dalam menerapkan logo, memiliki ciri khas agar terus dipertahankan. Untuk kegiatan selanjutnya adalah menambah jumlah produksi, dan inovasi baru dan melakukan kegiatan pameran baik dalam 
DINAMISIA - Jurnal Pengabdian Kepada Masyarakat Vol. 3, No. 2 Desember 2019, Hal. 180-188

maupun luar negeri, sehingga produk unggulan daerah Tegalwaru semakin dikenal luas dan menambah potensi saing UMKM dalam pemasaran, baik lokal maupun global.

\section{UCAPAN TERIMA KASIH}

Apresiasi dan terima kasih kepada Direktorat Riset dan Pengabdian Masyarakat, Dirjen Penguatan Riset dan Pengembangan, Kementerian Riset, Teknologi dan Pendidikan Tinggi yang telah membiayai kegiatan Penelitian Pengabdian Kepada Masyarakat Tahun 2019 dengan judul "Branding Kelompok Pengrajin Wayang Golek di Desa Tegalwaru Bogor untuk Meningkatkan Daya Saing UMKM Ekonomi Kreatif", dengan kontrak Nomor: 225/SP2H/PPM/DRPM/2019, tanggal 11 Maret 2019.

Terima kasih juga kepada LLDIKTI Wilayah III Jakarta dan Lembaga Penelitian dan Pengabdian Masyarakat Universitas Indraprasta PGRI yang telah membantu kegiatan penelitian ini melalui Kontrak Penelitian: 17/AKM/P2M/2019, Tanggal 27 Maret 2019. Dan Surat Perjanjian/Kontrak Penelitian UNINDRA Nomor: 0408/ SKP2M/LPPM/ UNINDRA/III/2019, Tanggal 29 Maret 2019.

\section{DAFTAR PUSTAKA}

[1] N. Zubaidah, "80 Kampus Kembangkan Produk Unggulan Daerah," sindonews.com, 2019. [Daring]. Tersedia pada: https://nasional.sindonews.com/read/1374698/144/80-kampuskembangkan-produk-unggulan-daerah-1548823477. [Diakses: 08-Agu-2019].

[2] "Arif Budimanta: Jangan Remehkan Investasi UMKM," cnnindonesia.com, 30-Jul-2019. [Daring]. Tersedia pada: https://www.cnnindonesia.com/ekonomi/20190730205826-97416922/arif-budimanta-jangan-remehkan-investasi-umkm.

[3] “https://goukm.id/tegal-waru-kampung-menjadi-percontohan/," goukm.id, 2016. [Daring]. Tersedia pada: https://goukm.id/tegal-waru-kampung-menjadi-percontohan/. [Diakses: 08Agu-2019].

[4] H. Yin Wong dan B. Merrilees, "A brand orientation typology for SMEs: a case research approach,” J. Prod. Brand Manag., vol. 14, no. 3, hal. 155-162, Mei 2005.

[5] R. Hafni dan A. Rozali, "Analisis Usaha Mikro, Kecil, dan Menengah (umkm) terhadap Penyerapan Tenaga Kerja di Indonesia," Ilmu Ekon. dan Stud. Pembang., vol. 15, no. 2, hal. 77-96, 2017.

[6] Y. Rukiah, "Makna Warna pada Wajah Wayang Golek. Jurnal Desain," J. Desain, vol. 2, no. 3, hal. 117-202, 2015.

[7] M. Murdani, S. Widayani, dan H. Hadromi, "Pengembangan Ekonomi Masyarakat Melalui Pemberdayaan Usaha Mikro Kecil dan Menengah (Studi di Kelurahan Kandri Kecamatan Gunungpati Kota Semarang)," J. Abdimas, vol. 23, no. 2, hal. 152-157, 2019.

[8] T. Tambunan, "Recent evidence of the development of micro, small and medium enterprises in Indonesia," J. Glob. Entrep. Res., vol. 9, no. 1, hal. 18, Des 2019.

[9] Y. Rohayati dan S. Wulandari, "Training needs analysis for MSMEs: how to improve training effectiveness," IOP Conf. Ser. Mater. Sci. Eng., vol. 277, no. 1, hal. 012030, Des 2017.

[10] D. Ioniţă, "Success and Goals: An Exploratory Research in Small Enterprises," Procedia Econ. Financ., vol. 6, no. 13, hal. 503-511, 2013. 